11

2

3

4

\title{
Functional Food Property of Honey Locust (Gleditsia triacanthos) Flowers
}

\author{
Chuan-Rui Zhang ${ }^{a}$, Amila A. Dissanayake ${ }^{a}$, Muraleedharan G. Nair ${ }^{a, b, *}$
}

a Bioactive Natural Products and Phytoceuticals Laboratory, Department of Horticulture, Michigan State University, East Lansing, Michigan, 48824, USA

${ }^{\mathrm{b}}$ College of Food and Agriculture Sciences, Chair of Date Palm Research, King Saud University, Riyadh, 11451, Saudi Arabia

*Corresponding author. 1066 Bogue Street, Room A420, East Lansing, Michigan, 48824, USA.

Tel.: +1 517353 0406; fax: +1 517353 0890. E-mail address: nairm@ msu.edu. 
2

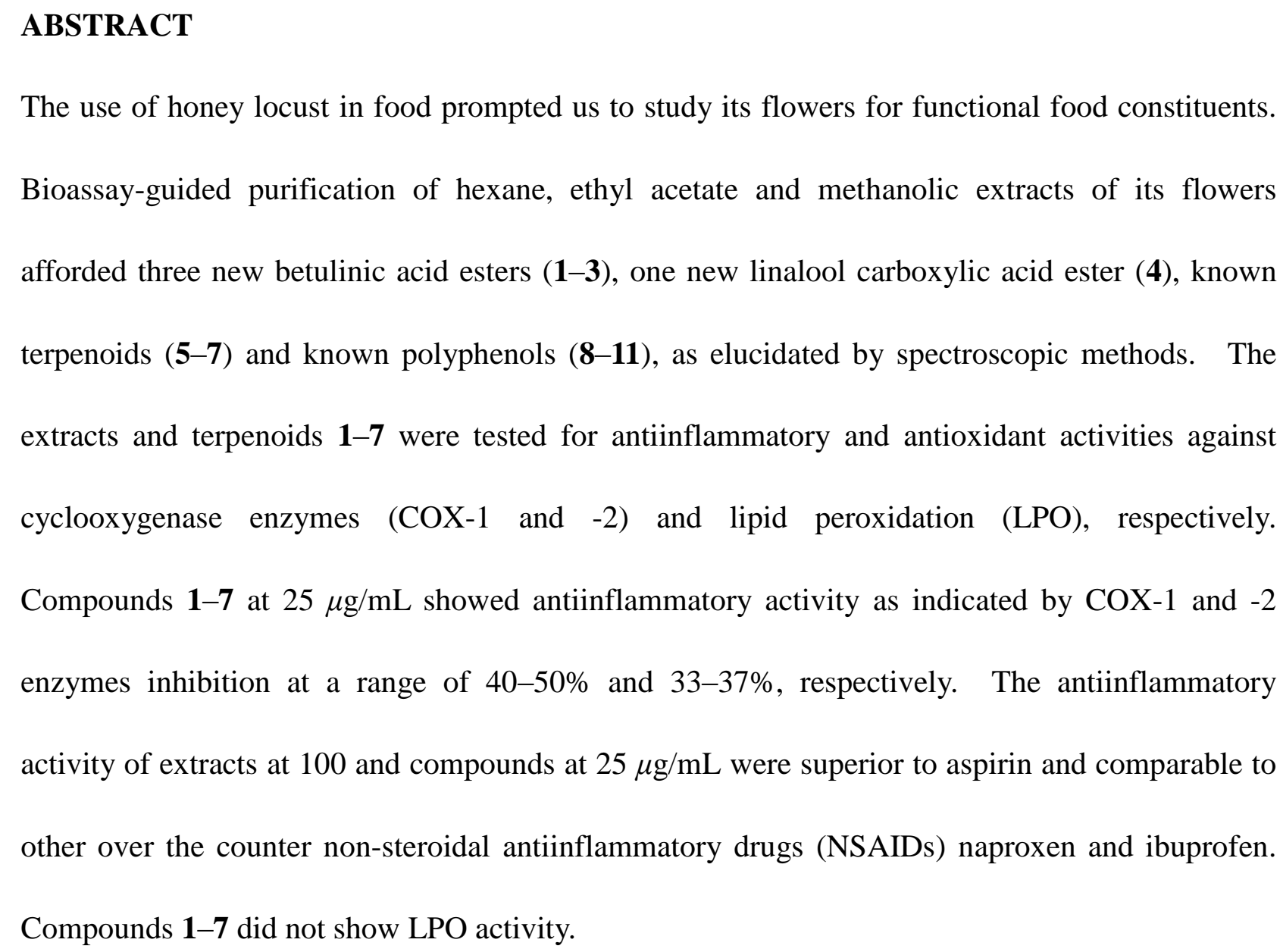

Keywords: Gleditsia triacanthos, betulinic acid derivatives, linalool carboxylic acid derivatives, phytoene, antiinflammatory

Chemical compounds: betulinic acid (PubChem CID: 64971); linalool (PubChem CID: 6549); (15Z)-phytoene (PubChem CID: 9963391); chlorogenic acid (PubChem CID: 1794427); neochlorogenic acid (PubChem CID: 5280633). 


\section{Introduction.}

The genus Gleditsia (Fabaceae) comprises about 16 species and several among them have long been used in traditional medicine. Gleditsia triacanthos L., the honey locust, is a deciduous tree native to North America and grown widely around the world (Little, 1979). The Native Americans used the pods of honey locust as a supplementary food source and medicines made from various parts of the plant (USDA Plants Database, 1996). The leaves of honey locust tree have been used to treat gastric and duodenal ulcer, colitis and cholecystitis in Bulgaria (Ivancheva \& Stantcheva, 2000). Similarly, leaves from honey locust trees in Egypt afforded flavonoids with antioxidant and cytotoxic activities (Mohammed, Abou Zeid, El Hawary, Sleem, \& Ashour, 2014) and flavonoids from leaves of Bulgarian honey locust (Panova \& Georgieva, 1972). The seeds from this tree in Portugal yielded phenolics and galactomannan (Cerqueira, Souza, Martins, Teixeira, \& Vicente, 2010). Phytochemical studies on its pericarp and seed in Uzbekistan gave triterpene glycoside, carbohydrates and lipids (Badalbaeva, Kondratenko, \& Abubakirov, 1973; Rakhmanberdyeva, Talipova, Gazizov, \& Rakhimov, 2002). Also, Sciarini et al. reported polysaccharides from Argentinean honey locust seeds (Sciarini, Maldonado, Ribotta, Pérez, \& León, 2009). Flowers of honey locust tree, although abundant, have not been investigated prior to this study. The lyophilized flowers of honey locust, collected from trees growing on the campus of Michigan State University, were sequentially extracted with hexane, ethyl acetate and methanol. The extracts and pure isolates were evaluated for antiinflammatory and antioxidant activities using in vitro cyclooxygenase enzymes (COX-1 and -2) (Kelm, Nair, Strasburg, \& DeWitt, 2000; Liu, Singh, \& Nair, 2012) and lipid peroxidation (LPO) (Arora, Nair, \& Strasburg, 1998; Liu et al., 2012) inhibitory assays, respectively. 


\section{Materials and methods}

\subsection{General Experimental Procedures}

All solvents used for isolation and purification were of ACS reagent grade (Sigma-Aldrich

Chemical Company, St. Louis, MO, USA). Merck silica gel (60 mesh size, 35-70 $\mu \mathrm{m}$, EMD Chemicals, Inc., Gibbstown, NJ, USA) was used for medium-pressure liquid chromatography (MPLC). 250 and $500 \mu \mathrm{m}$ silica gel plates (Analtech, Inc., Newark, DE, USA) were used for thin-layer chromatography (TLC). Optical rotations were measured on a Perkin-Elmer 341 polarimeter. ESIMS spectra were recorded on a Waters Xevo G2-S Q-TOF LC mass spectrometer (Waters Corporation, Milford, MA, USA). GCMS spectra were recorded on an Agilent 5973 mass spectrometer (Agilent Technologies, Palo Alto, CA, USA). NMR spectra were recorded on Agilent DirectDrive2 $500 \mathrm{MHz}$ or Varian Inova-500 instruments (Varian, Palo Alto, CA, USA). Aspirin, naproxen and ibuprofen were purchased from Sigma-Aldrich Chemical Company. The nonsteroidal anti-inflammatory drug (NSAIDs) Celeberex ${ }^{\circledR}$ was physician's professional sample. Cyclooxygenase (COX-1 and -2) enzymes were prepared in our laboratory from ram seminal vesicles purchased from Oxford Biomedical Research, Inc. (Oxford Biomedical Research, Inc., Oxford, MI, USA) and insect cells cloned with human PGHS-2 enzyme, respectively. Arachidonic acid was purchased from Oxford Biomedical Research, Inc. 1-Stearoyl-2-linoleoyl-sn-glycerol-3-phosphocholine (SLPC) was purchased from Avanti Polar Lipids (Alabaster, AL, USA). The fluorescent probe, 3-(p-(6-phenyl)-1,3,5-hexatrienyl) phenylpropionic acid was purchased from Molecular Probes (Eugene, OR, USA). All enzymes and reagents were stored in the Bioactive Natural Products and Phytoceuticals Laboratory at Michigan State University (East Lansing, MI). COX assays were performed in a micro oxygen chamber with 
oxygen electrode (Instech Laboratories, Plymouth Meeting, PA, USA) attached to an YSI model 5300 biological oxygen monitor (Yellow Springs Instrument, Inc., Yellow Springs, OH, USA). For Lipid Peroxidation (LPO) assay, the fluorescence of test compounds or extracts in assay buffer was measured on Turner model 450 Fluorometer (Barnstead Thermolyne Corporation, Dubuque, IA, USA).

\subsection{Extraction and isolation}

The flowers of honey locust, Gleditsia triacanthos L., were collected in May 2013, from trees grown on Michigan State University campus, and lyophilized. The powdered lyophilized flowers $(236 \mathrm{~g})$ were sequentially extracted with hexane $(2 \mathrm{~L} \times 3,8 \mathrm{~h})$, EtOAc $(2 \mathrm{~L} \times 3,8 \mathrm{~h})$ and $\mathrm{MeOH}(2 \mathrm{~L}$ $\times 3,8 \mathrm{~h}$ ) and evaporated under vacuum to afford honey locust (HL) hexane HLH (6.8 g), ethyl acetate HLE (6.2 g) and methanolic HLM (30.1 g) extracts, respectively.

An aliquot of the extract HLH (3.3 g) was fractionated by silica gel vacuum liquid chromatography (VLC) and eluted under gradient conditions using hexane, hexane-acetone (10:1, 5:1, 2:1, v/v) and acetone (100\%) to yield fractions A (233 mg), B (2.85 g) and C (262 mg). Fr. B (2.48 g) was purified by silica gel medium pressure liquid chromatography (MPLC) and eluted with hexane-acetone $(5: 1)$ to yield fractions B1 $(1.163 \mathrm{~g})$ and B2 (1.31 g). An aliquot of Fr. B1 $(1.124 \mathrm{~g})$ was further fractionated by MPLC by eluting with hexane-EtOAc $(10: 1, \mathrm{v} / \mathrm{v})$ to yield fractions B1a (875 mg) and B1b (242 mg). Fr. B1a (148 mg) was purified by preparative TLC using hexane- $\mathrm{CHCl}_{3},(5: 1, \mathrm{v} / \mathrm{v})$ as the mobile phase and afforded $\mathbf{6}(44 \mathrm{mg})$ and 7 (13 mg). Fr. C and Fr. B2 were combined based on identical TLC profiles. An aliquot of this combined fraction (400 mg) was fractionated by MPLC and eluted with hexane-EtOAc (5:1, 3:1, 1:1, v/v) to yield fractions C1 (90 mg), C2 (118 mg), C3 (105 mg) and C4 (75 mg). Purification of Fr. C1 (60 mg) 

38 390 40 41

by preparative TLC (hexane-EtOAc, 2:1, v/v) gave 1 (12.3 mg) and 2 (12.5 mg). Similarly, purification of Fr. C3 (50 mg) afforded $3(8.9 \mathrm{mg})$ (Fig. 1).

An aliquot of the extract HLE (3.9 g) was fractionated by MPLC by eluting with $\mathrm{CHCl}_{3}-\mathrm{MeOH}(50: 1,20: 1,10: 1,5: 1,3: 1, \mathrm{v} / \mathrm{v})$ and afforded fractions D (1849 mg), E (458 mg), F (607 mg), G (147 mg), H (206 mg), I (113 mg) and J (442 mg). The major component in Fr. D was chlorophyll. Fr. $\mathrm{H}(87 \mathrm{mg})$ was purified by preparative TLC $\left(\mathrm{CHCl}_{3}-\mathrm{MeOH}, 10: 1\right.$, v/v) to yield 4 (40 mg). Similarly, purification of Fr. I (61 mg) afforded 5 (28 mg).

The methanolic extract HLM (3.83 g) was successively stirred with ethyl acetate $(50 \mathrm{~mL} \times 3)$ and methanol $(50 \mathrm{~mL} \times 3)$ to yield EtOAc-soluble $(\mathrm{Fr} . \mathrm{K}, 684 \mathrm{mg})$ and insoluble (Fr. L, $3.15 \mathrm{~g})$ fractions. Fr. K showed identical TLC profile with the extract HLE and hence did not purify further. An aliquot of the Fr. L (2.7 g) was fractionated by MPLC (C18 column), eluted with $\mathrm{MeOH}-\mathrm{H}_{2} \mathrm{O}$ (gradient elution, 5:95, 50:50, 80:20, v/v) and finally with $\mathrm{MeOH}(100 \%)$ afforded fractions L1 (1.9 g) and L2 (712 mg). An aliquot of Fr. L1 (34 mg) was purified repeatedly by preparative TLC $\left(\mathrm{CHCl}_{3}-\mathrm{MeOH}, 2: 1 \mathrm{v} / \mathrm{v}\right)$ to yield $8(11 \mathrm{mg})$ and $9(10 \mathrm{mg})$. An aliquot of Fr. L2 (560 mg) was fractionated by MPLC (C18 column), eluted with $\mathrm{MeOH}-\mathrm{H}_{2} \mathrm{O}$ (gradient elution, 50:50, 60:40, 70:30, 80:20, 90:10, v/v) and then with $\mathrm{MeOH}(100 \%)$, and finally purified by preparative TLC $\left(\mathrm{CHCl}_{3}-\mathrm{MeOH}, 10: 1, \mathrm{v} / \mathrm{v}\right)$ yielded $\mathbf{1 0}(2 \mathrm{mg})$ and $\mathbf{1 1}(5 \mathrm{mg})$.

\subsubsection{Compound 1}

Colorless gum, for ${ }^{1} \mathrm{H}$ and ${ }^{13} \mathrm{C}$ NMR data, see Table 1, HRESIMS $m / z 1145.8923\left([\mathrm{M}+\mathrm{Na}]^{+}\right.$, calcd for $\left.\mathrm{C}_{70} \mathrm{H}_{122} \mathrm{O}_{10} \mathrm{Na}, 1145.8936\right)$.

\subsubsection{Compound 2}


Colorless gum, for ${ }^{1} \mathrm{H}$ and ${ }^{13} \mathrm{C}$ NMR data, see Table 1, HRESIMS $m / z$ 1400.1204 $\left([\mathrm{M}+\mathrm{Na}]^{+}\right.$,

2

148 calcd for $\left.\mathrm{C}_{86} \mathrm{H}_{152} \mathrm{O}_{12} \mathrm{Na}, 1400.1181\right)$.

5

6

179

9

1100

11

12

131

14

15

16

193 21

\subsubsection{Compound 3}

Colorless gum, for ${ }^{1} \mathrm{H}$ and ${ }^{13} \mathrm{C}$ NMR data, see Table 1 , HRESIMS $m / z$ 1400.1135 $\left([\mathrm{M}+\mathrm{Na}]^{+}\right.$, calcd for $\left.\mathrm{C}_{86} \mathrm{H}_{152} \mathrm{O}_{12} \mathrm{Na}, 1400.1181\right)$.

\subsubsection{Compound 4}

Colorless gum, $[\alpha]^{20}{ }_{\mathrm{D}}-19\left(c 0.21, \mathrm{CDCl}_{3}\right)$, for ${ }^{1} \mathrm{H}$ and ${ }^{13} \mathrm{C}$ NMR data, see Table 1 , HRESIMS $m / z 411.1628\left([\mathrm{M}+\mathrm{Na}]^{+}\right.$, calcd for $\left.\mathrm{C}_{18} \mathrm{H}_{28} \mathrm{O}_{9} \mathrm{Na}, 411.1631\right)$.

\subsubsection{Compound 5}

Colorless gum, ${ }^{1} \mathrm{H}$ NMR (500 MHz, DMSO): $\delta 6.83(1 \mathrm{H}, \mathrm{t}, J=7.6 \mathrm{~Hz}, \mathrm{H}-3), 5.88(1 \mathrm{H}, \mathrm{dd}, J=$ 17.1, 10.8 Hz, H-7), $5.38\left(1 \mathrm{H}, \mathrm{d}, J=7.8 \mathrm{~Hz}, \mathrm{H}-1^{\prime}\right), 5.29(1 \mathrm{H}, \mathrm{d}, J=4.9 \mathrm{~Hz},-\mathrm{OH}), 5.18(1 \mathrm{H}, \mathrm{d}, J=$ $17.1 \mathrm{~Hz}, \mathrm{H}-8 \mathrm{a}), 5.13(1 \mathrm{H}, \mathrm{brs},-\mathrm{OH}), 5.04(1 \mathrm{H}, \mathrm{d}, J=5.4 \mathrm{~Hz},-\mathrm{OH}), 4.99(1 \mathrm{H}, \mathrm{d}, J=10.8 \mathrm{~Hz}$, $\mathrm{H}-8 \mathrm{~b}), 4.60(1 \mathrm{H}, \mathrm{s},-\mathrm{OH}), 4.14(1 \mathrm{H}, \mathrm{dd}, J=9.8,4.8 \mathrm{~Hz},-\mathrm{OH}), 3.65\left(1 \mathrm{H}, \mathrm{dd}, J=11.5,5.1 \mathrm{~Hz}, \mathrm{H}-6^{\prime}\right.$ a), 3.10-3.50 (5H, m, H-2', 3', 4', 5', 6'b), 2.22, $2.13\left(2 \mathrm{H}, \mathrm{m}, \mathrm{H}_{2}-5\right), 1.78\left(3 \mathrm{H}, \mathrm{s}, \mathrm{H}_{3}-9\right), 1.52$ (2H, m, $\left.\mathrm{H}_{2}-4\right), 1.18$ (3H, s, $\left.\mathrm{H}_{3}-10\right) ;{ }^{13} \mathrm{C}$ NMR (125 MHz, DMSO): $\delta 166.4$ (C-1), 146.0 (C-3), 145.0 (C-7), 126.7 (C-2), 111.9 (C-8), 94.9 (C-1'), 78.1 (C-3'), 76.6 (C-5'), 72.7 (C-6), 71.8 (C-2'), 69.8 (C-4'), $60.8\left(\mathrm{C}-6^{\prime}\right), 48.9$ (C-5), 28.1 (C-10), 23.8 (C-4), 12.5 (C-9). Compound 5 was characterized as $\beta$-D-glucopyranose 1-[(2E)-6-hydroxy-2,6-dimethyl-2,7-octadienoate] (D'Ambrosio, Harghel, \& Guantieri, 2013).

\subsubsection{Compound 6}

Colorless gum, ${ }^{1} \mathrm{H}$ NMR $\left(500 \mathrm{MHz}, \mathrm{CDCl}_{3}\right): \delta 5.36(4 \mathrm{H}, \mathrm{m},-\mathrm{CH} H \mathrm{CH}-), 5.11(1 \mathrm{H}, \mathrm{t}, J=6.8$ 
26
247 28

298 30 31

$\mathrm{Hz}, \mathrm{H}-24), 4.58(1 \mathrm{H}, \mathrm{m}, \mathrm{H}-3), 2.78\left(2 \mathrm{H}, \mathrm{m},-\mathrm{CH}=\mathrm{CH}-\mathrm{CH}_{2}-\mathrm{CH}=\mathrm{CH}-\right), 2.31\left(2 \mathrm{H}, \mathrm{m},-\mathrm{COCH}_{2^{-}}\right)$, $2.06\left(4 \mathrm{H}, \mathrm{m},-\mathrm{CH}=\mathrm{CH}-\mathrm{CH}_{2^{-}}\right), 1.70,1.62$ (each $\left.3 \mathrm{H}, \mathrm{s}, \mathrm{H}_{3}-26,27\right), 0.97$ (3H, s, $\left.\mathrm{H}_{3}-29\right), 0.90,0.89$ $\left(12 \mathrm{H}, \mathrm{s}, \mathrm{H}_{3}-18,21,30,-\mathrm{CH}_{3}\right), 0.85\left(3 \mathrm{H}, \mathrm{s}, \mathrm{H}_{3}-28,\right), 0.58(1 \mathrm{H}, \mathrm{d}, J=3.7 \mathrm{~Hz}, \mathrm{H}-19 \mathrm{a}), 0.35$ (1H, d, $J$ = $3.7 \mathrm{~Hz}, \mathrm{H}-19 \mathrm{~b}$ ). Compound 6 was identified as cycloartenyl linoleate (Arai, Shiojima, \& Ageta, 1989).

\subsubsection{Compound 7}

Colorless powder, ${ }^{1} \mathrm{H}$ NMR $\left(500 \mathrm{MHz}, \mathrm{CDCl}_{3}\right): \delta 6.30\left(2 \mathrm{H}, \mathrm{d}, J=9.8 \mathrm{~Hz}, \mathrm{H}-14,14{ }^{\prime}\right), 6.10$ $\left(2 \mathrm{H}, \mathrm{d}, J=9.8 \mathrm{~Hz}, \mathrm{H}-15,15^{\prime}\right), 5.09-5.14\left(6 \mathrm{H}, \mathrm{m}, \mathrm{H}-2,6,10,2^{\prime}, 6^{\prime}, 10^{\prime}\right), 1.94-2.16\left(24 \mathrm{H}, \mathrm{m}, \mathrm{H}_{2}-3\right.$, $\left.4,7,8,11,12,3^{\prime}, 4^{\prime}, 7^{\prime}, 8^{\prime}, 11^{\prime}, 12^{\prime}\right), 1.77,1.68,1.62,1.60,1.59\left(\right.$ each $\left.6 \mathrm{H}, \mathrm{s},-\mathrm{CH}_{3}\right) ;{ }^{13} \mathrm{C}$ NMR $(125$ $\left.\mathrm{MHz}, \mathrm{CDCl}_{3}\right): \delta 139.5\left(\mathrm{C}-15,5^{\prime}\right), 135.3\left(\mathrm{C}-9,9^{\prime}\right), 134.9\left(\mathrm{C}-5,5^{\prime}\right), 131.2\left(\mathrm{C}-1,1^{\prime}\right), 124.4(\mathrm{C}-10$, 10'), $124.2\left(\mathrm{C}-6,6^{\prime}\right), 124.0\left(\mathrm{C}-2,2^{\prime}\right), 123.3\left(\mathrm{C}-13,13^{\prime}\right), 120.2\left(\mathrm{C}-9,9^{\prime}\right), 40.5\left(\mathrm{C}-12,12^{\prime}\right), 39.7$ (C-4, 8, 4', 8'), $26.7\left(\mathrm{C}-7,11,7^{\prime}, 1^{\prime}\right), 25.7\left(\mathrm{C}-3,3^{\prime}\right), 17.7\left(\mathrm{C}-1,1^{\prime}\right), 16.5\left(\mathrm{C}-13,13^{\prime}\right), 16.0\left(\mathrm{C}-5,9,5^{\prime}, 9^{\prime}\right)$. Compound 7 was identified as (15Z)-phytoene (Granger, Maudinas, Herber, \& Villoutrei, 1973).

\subsection{ESIMS analyses of compounds $\mathbf{1 - 4}$.}

ESIMS spectra were recorded on a Waters Xevo G2-S Q-TOF LC mass spectrometer by flow injection analysis (FIA) experiments. An aliquot of $10 \mu \mathrm{L}$ of samples was injected and eluted with methanol for 2 min under isocratic condition. The mass range of 50-1500 under electro spray ionization (ESI) positive ion mode was used for the detection of peaks.

\subsection{Hydrolysis of compounds 1-3 and GCMS analyses of fatty acid methyl esters.}

An aliquot of 1-3 (1 mg) was stirred with $\mathrm{KOH}$ in $\mathrm{MeOH}(3 \mathrm{M})(3 \mathrm{~h})$ separately, acidified with $\mathrm{HCl}$ and evaporated. The resulting fatty acid mixture was then methylated with $\mathrm{CH}_{2} \mathrm{~N}_{2}$ separately 
to afford fatty acid methyl esters, according to the reported procedure (Ramsewak, Nair,

2

160

5

181

8

192 10

11

Murugesan, Mattson, \& Zasada, 2001). The methyl esters thus obtained from 1-3 were analyzed separately on a GC capillary column, Agilent J\&W VF-5ms GC Column, 30 m x 0.25 mm, 0.25 $\mu \mathrm{m}$ film thickness attached to a $10 \mathrm{~m}$ EZ-Guard column with a 7 inch cage. The conditions for the analyses were $1 \mu \mathrm{L}$ sample dissolved in hexane, helium carrier gas at a flow rate of $1.5 \mathrm{~mL} / \mathrm{min}$ with a split ratio of 10:1 and temperature gradient with an injector port temperature at $240{ }^{\circ} \mathrm{C}$, held for $2 \mathrm{~min}$, raised to $320^{\circ} \mathrm{C}$ at a rate of $40{ }^{\circ} \mathrm{C}$ and held for another $10 \mathrm{~min} .1$ gave two peaks at $\mathrm{R}_{\mathrm{t}}$ $=6.687$ and $7.201 \mathrm{~min}$ with $\mathrm{m} / \mathrm{z}$ values of 270 and 298 , respectively for methyl esters of palmitic and stearic acids. Similarly, 2 and $\mathbf{3}$ gave peaks at $\mathbf{R}_{t}=6.693,7.100$ and 7.214 with $\mathrm{m} / \mathrm{z}$ values of 270, 286 and 298 respectively for methyl esters of palmitic, hydroxy-palmitic and stearic acids.

\subsection{Cyclooxygenase enzymes (COX-1 and -2) inhibitory assays.}

The COX-1 and -2 enzyme inhibitory activities were measured for extracts at $100 \mu \mathrm{g} / \mathrm{mL}$, compounds 1-7 at $25 \mu \mathrm{g} / \mathrm{mL}(22,18,18,61,72,36$ and $46 \mu \mathrm{M}$, respectively) and the positive controls Aspirin, Ibuprofen, Celebrex, and Naproxen at 108, 12, 1 and $15 \mu \mathrm{g} / \mathrm{mL}$ (600, 60, 2.6 and $60 \mu \mathrm{M}$ ), respectively, according to the published procedure (Kelm et al., 2000; Liu et al., 2012). The assay was carried out by monitoring the initial rate of $\mathrm{O}_{2}$ uptake using an Instech micro oxygen chamber and electrode attached to an YSI model 5300 Biological Oxygen Monitor at $37^{\circ} \mathrm{C}$. The test samples $(6 \mu \mathrm{L})$ were initially added to the chamber full of assay buffer ( $1 \mathrm{mM}$ Tris-phenol buffer, $600 \mu \mathrm{L}, \mathrm{pH}=7$, and hemoglobin $(17 \mu \mathrm{g}))$. COX-1 or -2 enzymes $(20 \mu \mathrm{L})$ was then added and incubated for $2 \mathrm{~min}$. The substrate arachidonic acid $(10 \mu \mathrm{L}$ of solution at $1 \mathrm{mg} / \mathrm{mL} 1 \mathrm{mM}$ Tris-phenol buffer, $\mathrm{pH}=7$ ) was added to initiate the enzyme reaction or formation of prostaglandin endoperoxide. The data were recorded using QuickLog for windows data acquisition. The percent 

20

inhibition was calculated with respect to DMSO control and each sample was tested in duplicate.

\subsection{Lipid peroxidation inhibitory (LPO) assay}

LPO inhibitory activity was measured for the extract at $100 \mu \mathrm{g} / \mathrm{mL}$, compounds $\mathbf{1}-\mathbf{5}$ at 25 $\mu \mathrm{g} / \mathrm{mL}(22,18,18,61$ and $72 \mu \mathrm{M}$, respectively), compounds 6 and 7 at $5 \mu \mathrm{g} / \mathrm{mL}(7.3$ and $9.2 \mu \mathrm{M}$, respectively), and positive controls BHA (butylated hydroxyanisole), BHT (butylated hydroxytoluene) and TBHQ (tert-butylhydroquinone) at 1.802, 2.204 and $1.662 \mu \mathrm{g} / \mathrm{mL}(10,10$ and $10 \mu \mathrm{M}$ ), respectively, according to previous report (Arora et al., 1998; Liu et al., 2012). The peroxidation was initiated by adding $20 \mu \mathrm{L}$ of $\mathrm{FeCl}_{2} \cdot 4 \mathrm{H}_{2} \mathrm{O}(0.5 \mathrm{mM})$ to the assay mixture [HEPES $(100 \mu \mathrm{L}), 1 \mathrm{M} \mathrm{NaCl}(200 \mu \mathrm{L}), \mathrm{N}_{2}$-sparged Millipore water (1.64 mL), DMSO (dimethyl sulphoxide) or test sample $(20 \mu \mathrm{L})]$ and $20 \mu \mathrm{L}$ of liposome suspension. The fluorescence was monitored at $0,1,3$ and every 3 min thereafter up to 21 min on a Turner model 450 Fluorometer.

The decrease in fluorescence intensity over time $(21 \mathrm{~min})$ indicated the rate of peroxidation. The percent inhibition was calculated with respect to DMSO control and each sample was assayed in duplicate.

\section{Results and discussion}

A preliminary lipid peroxidation (LPO) assay carried out using our published procedure for the extracts showed hexane (HLH) extract as the most active at $100 \mu \mathrm{g} / \mathrm{mL}$ (Arora et al., 1998; Liu et al., 2012). However, all extracts showed good COX-1 and -2 enzyme inhibition (Fig. 2) (Kelm et al., 2000; Liu et al., 2012). Based on the COX enzyme inhibitory activity, each extract was purified by chromatographic methods to afford pure and active isolates. Structures of all pure isolates (1-11) were determined by ${ }^{1} \mathrm{H}-$ and ${ }^{13} \mathrm{C}-\mathrm{NMR}, 2 \mathrm{D}-\mathrm{NMR}$ and MS analyses (Fig. 1). 

13

However, detailed structure elucidation presented in this manuscript is only for new compounds (1-4). Structures of known compounds (5-11) were identified based on the comparison of ${ }^{1} \mathrm{H}$ and ${ }^{13} \mathrm{C}$ NMR spectral data with the published spectral data of these compounds. As described in the experimental methods section, purification of hexane (HLH) extract yielded compounds 1-3, 6 and 7. Compounds $\mathbf{4}$ and $\mathbf{5}$ were isolated from the ethyl acetate extract (HLE). Similarly, purification of methanolic extract (HLM) yielded compounds chlorogenic acid (8) (Li \& Ho, 2006), neochlorogenic acid (9) (Li et al., 2006), 5,3',4'-trihydroxyflavanone 7-glucoside (10) (Liu et al., 2012) and luteolin (11) (Park et al., 2007) as major bioactive constituents.

\subsection{Structure elucidation of new compounds}

Compound 1, a colorless gum, possessed the molecular formula of $\mathrm{C}_{70} \mathrm{H}_{122} \mathrm{O}_{10}$, as determined by HRESIMS ions at $m / z 1145.8923\left([\mathrm{M}+\mathrm{Na}]^{+}\right.$, calcd 1145.8936) (Fig. 1). The NMR data of $\mathbf{1}$ revealed that it contained a betulinic acid $28-O-\beta$-glucopyranoside moiety (Chatterjee, Pezzuto, \& Kouzi, 1999) and displayed characteristic signals of ester carbonyl ( $\left.\delta_{\mathrm{C}} 174.3, \mathrm{C}-28\right)$, terminal double bond $\left(\delta_{\mathrm{C}} 150.2, \mathrm{C}-20, \delta_{\mathrm{C}} 109.8, \delta_{\mathrm{H}} 4.75,4.62, \mathrm{CH}_{2}-29\right), \beta$-glucose moiety, oxygenated methine $\left(\delta_{\mathrm{C}} 80.5, \delta_{\mathrm{H}} 4.49, \mathrm{CH}-3\right)$, and six tertiary methyls $\left(\delta_{\mathrm{H}} 1.70,0.97,0.91,0.85,0.84,0.84\right)$ (Table 1). In addition, the NMR spectra of 1 showed proton and carbon signals with chemical shifts that were characteristic of long chain fatty acid esters. The above-mentioned data suggested that $\mathbf{1}$ was a long chain fatty acid ester of betulinic acid $28-O-\beta$-glucopyranoside. One of the fatty acid esters was assigned at C-3 on the basis of HMBC correlations observed, H-3/C-23, H-3/C-24, H-3/C-1", H-2/C-3, Me-23/C-3, Me-24/C-3, $\mathrm{H}_{2}-2 " / C-1 ", \mathrm{H}_{2}-2 " / C-3 "$, and H-3"/C-1". The second fatty acid ester group was placed at C-3' based on HMBC correlations of $\mathrm{H}-3^{\prime} / \mathrm{C}-2^{\prime}$, 
$\mathrm{H}-3^{\prime} / \mathrm{C}-4^{\prime}, \mathrm{H}-3^{\prime} / \mathrm{C}-1^{\prime \prime \prime}, \mathrm{H}-2^{\prime} / \mathrm{C}-3^{\prime}, \mathrm{H}-4^{\prime} / \mathrm{C}-3^{\prime}, \mathrm{H}_{2}-2^{\prime \prime \prime} / \mathrm{C}-1^{\prime \prime \prime}, \mathrm{H}_{2}-2^{\prime \prime \prime} / \mathrm{C}-3^{\prime \prime \prime}$, and $\mathrm{H}_{2}-3^{\prime \prime \prime} / \mathrm{C}-1^{\prime \prime \prime}$. The

ESIMS fragments, 255 and 283, suggested the presence of palmitic $\left(\mathrm{C}_{16} \mathrm{H}_{32} \mathrm{O}_{2}\right)$ and stearic $\left(\mathrm{C}_{18} \mathrm{H}_{36} \mathrm{O}_{2}\right)$ acids. 1 was hydrolyzed and methylation of the resulting product afforded the corresponding fatty acid methyl esters. GCMS analysis of the resulting fatty acid ester mixture gave molecular ions at $\mathrm{m} / \mathrm{z} 270$ (methyl palmitate) and 298 (methyl stearate) further confirmed the HRESIMS of 1 and its proposed structure. However, C-16 and C-18 ester substituents at C-3 and C-3' shall be interchanged. The relative stereochemistry of $\mathbf{1}$, assigned based on NMR chemical shifts and 2D NMR correlations, was identical to the published relative stereochemistry of betulinic acid 28-O- $\beta$-glucopyranoside (Chatterjee et al., 1999; Gauthier, Legault, Rondeau, \& Pichette, 2009). The orientation of the fatty acid ester moiety in $\mathbf{1}$ at $\mathrm{C}-3$ was established as $\beta$ based on the ROESY correlations of $\mathrm{H}-3 / \mathrm{H}-5$ and H-3/Me-23. The fatty acid ester on the glucose moiety at C-3' was also $\beta$-oriented based on the ROESY correlations of $\mathrm{H}-3^{\prime} / \mathrm{H}-1^{\prime}$ and $\mathrm{H}-3^{\prime} / \mathrm{H}-5^{\prime}$. Therefore, the structure of compound $\mathbf{1}$ was established as shown in Fig. 1.

A colorless gum, compound 2 (Fig. 1), gave the molecular formula of $\mathrm{C}_{86} \mathrm{H}_{152} \mathrm{O}_{12}$ as determined by HRESIMS ion at $m / z$ 1400.1204 ([M + Na $]^{+}$, calcd 1400.1181). The NMR data of 2 also showed characteristic signals of betulinic acid 28-O- $\beta$-glucopyranoside moiety (Chatterjee et al., 1999) and long chain fatty acid esters (Table 1). Similar to 1, two fatty acid esters were assigned at C-3 and C-3' on the basis of HMBC correlations. Compound 2 showed proton and carbon signals for oxygenated methine $\left(\delta_{\mathrm{C}} 70.5, \delta_{\mathrm{H}} 5.21, \mathrm{~m}\right)$ at C-3" and fatty acid ester moieties to C-3" (Table 1). It was supported by ${ }^{1} \mathrm{H}-{ }^{1} \mathrm{H}$ COSY correlations of $\mathrm{H}_{2}-2$ " $/ \mathrm{H}-3$ ", $\mathrm{H}-3$ " $/ \mathrm{H}_{2}-4$ " and the HMBC correlations of H-3/C-23, H-3/C-24, H-3/C-1", H-2/C-3, Me-23/C-3, Me-24/C-3, $\mathrm{H}_{2}-2^{\prime \prime} / \mathrm{C}-1 ", \mathrm{H}_{2}-2^{\prime \prime} / \mathrm{C}-3 ", \mathrm{H}_{2}-2^{\prime \prime} / \mathrm{C}-4^{\prime \prime}, \mathrm{H}-3 " / \mathrm{C}-1^{\prime \prime}, \mathrm{H}-3^{\prime \prime} / \mathrm{C}-2^{\prime \prime}, \mathrm{H}-3 " / \mathrm{C}-1^{\prime \prime \prime}, \mathrm{H}_{2}-2^{\prime \prime \prime} / \mathrm{C}-1^{\prime \prime \prime}$ and 
$\mathrm{H}_{2}-3^{\prime \prime \prime \prime} / \mathrm{C}-1$ "'". The fatty acid ester moieties in $\mathbf{2}$ were also determined by ESIMS and GCMS of the fatty acid methyl esters obtained from its hydrolysis. GCMS analyses of the fatty acid methyl

5 esters gave molecular ions at $\mathrm{m} / \mathrm{z} 270$ (methyl palmitate), 286 (3-hydroxyl methyl palmitate) and 298 (methyl stearate). The assignments of C-16 and C-18 ester substituents at C-3, C-3' and C-3" are interchangeable as in the case of compound $\mathbf{1}$. The relative stereochemistry of $\mathbf{2}$ was identical to compound $\mathbf{1}$ based on NMR data. We did not determine the stereochemistry of the fatty acid ester moiety at C-3" of the fatty acid connected to C-3 of betulinic acid.

Compound 3 (Fig. 1) with the molecular formula $\mathrm{C}_{86} \mathrm{H}_{152} \mathrm{O}_{12}$, as determined by HRESIMS, showed NMR signals belonging to betulinic acid 28-O- $\beta$-glucopyranoside moiety (Chatterjee et al., 1999) as in compounds $\mathbf{1}$ and $\mathbf{2}$. It also contained three long chain fatty acid ester functionalities as determined by NMR (Table 1) and GCMS analyses of its hydrolyzed product. The fatty acid esters in the molecule were assigned at C-3, C-3' and C-6 based on HMBC correlations. The assignment of C-6' was further based on the downfield shift of $\mathrm{H}_{2}-6^{\prime}$ (Table 1). 3 showed proton and carbon signals for oxygenated methine $\left(\delta_{\mathrm{C}} 68.2, \delta_{\mathrm{H}} 4.02, \mathrm{~m}\right)$, which was assigned to C-3"'" based on the ${ }^{1} \mathrm{H}-{ }^{1} \mathrm{H}$ COSY correlations of $\mathrm{H}_{2}-2^{2 \prime \prime \prime} / \mathrm{H}-3^{\prime \prime \prime \prime}, \mathrm{H}-3^{\prime \prime \prime \prime} / \mathrm{H}_{2}-4^{\prime \prime \prime}$ and the HMBC correlations of $\mathrm{H}_{2}-2^{\prime \prime \prime \prime} / \mathrm{C}-1{ }^{\prime \prime \prime}, \mathrm{H}-2^{\prime \prime \prime} / \mathrm{C}-3^{\prime \prime \prime}$. The GCMS of the fatty acid methyl esters obtained from its hydrolysis gave molecular ions at $\mathrm{m} / \mathrm{z} 270$ (methyl palmitate), 286 (3-hydroxyl methyl palmitate) and 298 (methyl stearate). The fatty acid ester moieties were interchangeable at C-3, C-3' and C-6' since they were not discernable by NMR data. The relative stereochemistry of $\mathbf{3}$ was same as compounds $\mathbf{1}$ and $\mathbf{2}$ based on NMR data. We did not determine the stereochemistry of the $-\mathrm{OH}$ moiety at C-3"' of the fatty acid connected to C-6' of the glucose. 
Although not evident in the NMR spectra, minute amounts of other betulinic acid 28-O- $\beta$-glucopyranoside esters were detected in the ESIMS spectra of isolates 1-3. They were assigned as homologues fatty acid esters, accounting to mass differences of $28\left(\mathrm{CH}_{2}-\mathrm{CH}_{2}\right)$, in molecules $\mathrm{C}_{68} \mathrm{H}_{118} \mathrm{O}_{10}, \mathrm{C}_{72} \mathrm{H}_{126} \mathrm{O}_{10}, \mathrm{C}_{84} \mathrm{H}_{148} \mathrm{O}_{12}$ and $\mathrm{C}_{88} \mathrm{H}_{156} \mathrm{O}_{12}$ as indicated at $m / z$ 1117.8622 $([\mathrm{M}+$ $\left.\mathrm{Na}]^{+}\right), 1173.9246\left([\mathrm{M}+\mathrm{Na}]^{+}\right), 1372.0837\left([\mathrm{M}+\mathrm{Na}]^{+}\right)$and $1428.1449\left([\mathrm{M}+\mathrm{Na}]^{+}\right)$, respectively.

Compound 4, obtained as a colorless gum from ethyl acetate (HLE) extract, showed HRESIMS ion at $m / z 411.1628\left([\mathrm{M}+\mathrm{Na}]^{+}\right.$, calcd 411.1631) corresponding to the molecular formula of $\mathrm{C}_{18} \mathrm{H}_{28} \mathrm{O}_{9}$. Comparisons of the NMR spectra of $\mathbf{4}$ and known compound $\mathbf{5}$ indicated that $\mathbf{4}$ was the acetyl ester of $\mathbf{5}$ at C-6' based on the downfield shift of $\mathrm{H}_{2}-6^{\prime}$ (Table 1) and $\mathrm{HMBC}$ correlations of $\mathrm{H}_{2}-6^{\prime} / \mathrm{C}-1^{\prime \prime}$ and $\mathrm{Me}-2^{\prime \prime} / \mathrm{C}-1^{\prime \prime}$.

\subsection{Antiinflammatory, antioxidant and human tumor cell growth inhibitory activities}

Among the compounds isolated and characterized by NMR and MS spectral methods, only terpenoids 1-7 were tested in in vitro antiinflammatory, antioxidant and human tumor cell growth inhibitory assays. This was because known polyphenols $\mathbf{8}-\mathbf{1 1}$ isolated from the methanolic extract have already been studied for their antioxidant (Liu et al., 2012; Nakatani et al., 2000; Wang, Nair, Strasburg, Booren, \& Gray, 1999), antiinflammatory (Liu et al., 2012; Seo, Lim, Jeong, \& Shin, 2013; Wang et al., 2000) and anticancer activities (Huang, Smart, Wong, \& Conney, 1988; Liu et al., 2012; Nakatani et al., 2000; Roleira et al., 2015).

The antiinflammatory activity was determined by measuring the inhibition of cyclooxygenase enzymes COX -1 and -2 , which play an important role in the inflammatory processes by converting arachidonic acid to prostaglandins that up regulate inflammatory responses in vivo (Kelm et al., 
2000; Liu et al., 2012). At $100 \mu \mathrm{g} / \mathrm{mL}$, hexane, ethyl acetate and methanolic extracts showed COX-1 enzyme inhibition by 46, 52 and 49\%, respectively (Fig. 2). The terpenoids 1-7 at 25 5 $\mu \mathrm{g} / \mathrm{mL}$ or $22,18,18,61,72,36$ and $46 \mu \mathrm{M}$, respectively, inhibited COX-1 enzyme by 44, 44, 44, 42, 42, 40 and 50\%, and COX-2 enzyme by 33, 34, 34, 33, 37, 37 and 34\%, respectively (Fig. 2). The COX-1 enzyme inhibitory activity of compounds $\mathbf{1}-\mathbf{7}$ at $25 \mu \mathrm{g} / \mathrm{mL}$ or $22,18,18,61,72,36$ and $46 \mu \mathrm{M}$, respectively, was superior to the inhibitory activity of aspirin tested at $108 \mu \mathrm{g} / \mathrm{mL}$ (600 $\mu \mathrm{M})$. Also, the enzyme inhibitory activity of these terpenoids was similar to ibuprofen and naproxen, used as positive controls, at 12 and $15 \mu \mathrm{g} / \mathrm{mL}$ (60 and $60 \mu \mathrm{M}$ ), respectively. Amongst the terpenoids tested, (15Z)-phytoene (7) showed the highest COX-1 enzyme inhibition. It is important to note that all extracts and isolates from honey locust flowers tested showed higher COX-1 than COX-2 enzyme inhibition, similar to over the counter non-steroidal antiinflammatory drugs (NSAIDs) aspirin, naproxen and ibuprofen. The varying concentrations of positive controls used were to yield a comparable inhibitory activity values between $50-100 \%$ by test extracts, compounds and positive controls alike. It is our experience that bioactive compounds in functional food and generally regarded as safe (GRAS) plants are usually less potent than positive controls used in the bioassays.

The antioxidant activity of honey locust flower extract and isolated compounds were determined by lipid peroxidation inhibitory (LPO) assay. This assay is specific for identifying compounds with free radical scavenging ability (Arora et al., 1998; Liu et al., 2012). The results showed that the hexane extract (HLH), ethyl acetate extract (HLE) and methanolic extract (HLM) of honey locust flowers at $100 \mu \mathrm{g} / \mathrm{mL}$ inhibited LPO by 85,29 and $44 \%$, respectively, while terpenoids $\mathbf{1}-\mathbf{5}$ at $25 \mu \mathrm{g} / \mathrm{mL}(22,18,18,61$ and $72 \mu \mathrm{M}$, respectively) and 6-7 at $5 \mu \mathrm{g} / \mathrm{mL}(7.3$ and 
$9.2 \mu \mathrm{M}$, respectively) by about $25 \%$. This weak activity can be explained due to the poor solubility of these compounds in the assay buffer. We were unable to test these compounds at higher concentrations due to precipitation in assay buffer. Poly phenols 8-11 from HLM were not assayed since its LPO activity has already been reported (Liu et al., 2012; Nakatani et al., 2000; Wang et al., 1999). In order to determine the cytotoxicity of these compounds, the extracts from honey locust flowers and its isolates were evaluated for tumor cell proliferation inhibitory activity against AGS (gastric), DU-145 and LNCaP (prostate), HCT-116 (colon), MCF-7 (breast) and NCI-H460 (lung) human tumor cell lines (Liu \& Nair, 2011). The results showed that extracts at $100 \mu \mathrm{g} / \mathrm{mL}$ and compounds $\mathbf{1}-\mathbf{7}$ at $25 \mu \mathrm{g} / \mathrm{mL}$ or $22,18,18,61,72,36$ and $46 \mu \mathrm{M}$, respectively, did not inhibit tumor cell proliferation.

\section{Conclusion}

This is the first report on the chemistry and bioactivity of honey locust flowers. The extracts and compounds isolated from the extracts showed antiinflammatory activity similar to nonsteroidal anti-inflammatory drugs (NSAIDs), aspirin, ibuprofen and naproxen, as confirmed determined by COX-1 and -2 enzymes inhibition. Carotenoids and polyphenols are rich in fruits and vegetables and widely reported for its health-benefits. Carotenoids such as $\beta$-carotene, lycopene, lutein, phytofluene and phytoene are significant ingredients in dietary supplements sold in the market. Our results confirm the presence of several of these active compounds in honey locust flowers and its significant antiinflammatory activity. Therefore, it appears that honey locust flowers have the potential to be developed as a dietary supplement.

\section{Acknowledgements}


data were obtained on instrumentation that was purchased, in part, with the funds from NIH grant no. 1-S10-RR04750, NSF grant no. CHE-88-00770, and NSF grant no. CHE-92-13241. MS data were obtained at the Michigan State University Mass Spectrometry Facility, which is supported, in part, by a grant (DRR-00480) from the Biotechnology Research Technology Program, National Center for Research Resources, National Institutes of Health.

\section{References}

Arai, Y., Shiojima, K., \& Ageta, H. (1989). Fern constituents: cyclopodmenyl acetate, a cycloartanoid having a new 33-carbon skeleton, isolated from Polypodium Vulgare. Chemical \& Pharmaceutical Bulletin, 37, 560-562.

Arora, A., Nair, M. G., \& Strasburg, G. M. (1998). Antioxidant activities of isoflavones and their biological metabolites in a liposomal system. Archives of Biochemistry and Biophysics, 356, $133-141$.

Badalbaeva, T. A., Kondratenko, E. S., \& Abubakirov, N. K. (1973). Triterpene glucosides of Gleditsia triacanthos V. Structure of triacanthoside C and the minor glycosides. Khimiya Prirednykh Soedinenii, 635-640.

Cerqueira, M. A., Souza, B. W. S., Martins, J. T., Teixeira, J. A., \& Vicente, A. A. (2010). Seed extracts of Gleditsia triacanthos: Functional properties evaluation and incorporation into galactomannan films. Food Research International, 43, 2031-2038.

Chatterjee, P., Pezzuto, J. M., \& Kouzi, S. A. (1999). Glucosidation of betulinic acid by Cunninghamella species. Journal of Natural Products, 62, 761-763. 
D'Ambrosio, M., Harghel, P., \& Guantieri, V. (2013). Isolation of intact glycosidic aroma precursors from grape juice by hydrophilic interaction liquid chromatography. Australian Journal of Grape and Wine Research, 19, 189-192.

Gauthier, C., Legault, J., Rondeau, S., \& Pichette, A. (2009). Synthesis of betulinic acid acyl glucuronide for application in anticancer prodrug monotherapy. Tetrahedron Letters, 50, 988-991.

Granger, P., Maudinas, B., Herber, R., \& Villoutrei, J. (1973). ${ }^{1} \mathrm{H}$ and ${ }^{13} \mathrm{C}$ NMR spectra of cis and trans phytoene isomers. Journal of Magnetic Resonance, 10, 43-50.

Huang, M.-T., Smart, R. C., Wong, C.-Q., \& Conney, A. H. (1988). Inhibitory effect of curcumin, chlorogenic acid, caffeic acid, and ferulic acid ferulic acid on tumor promotion in mouse skin by 12-O-tetradecanoylphorbol- 13-acetate. Cancer Research, 48, 5941-5946.

Ivancheva, S., \& Stantcheva, B. (2009). Ethnobotanical inventory of medicinal plants in Bulgaria. Journal of Ethnopharmacology, 69, 165-172.

Kelm, M. A., Nair, M. G., Strasburg, G. M., \& DeWitt, D. L. (2000). Antioxidant and cyclooxygenase inhibitory phenolic compounds from Ocimum sanctum Linn. Phytomedicine, 7 , $7-13$.

Li, S., \& Ho, C.-T. (2006). In Herbs: Challenges in Chemistry and Biology. In M. Wang, S. Sang, L. S. Hwang, \& C.-T. Ho (Eds.), ACS Symposium Series Vol. 925, pp. 240-253.

Little, E. L., Jr. 1979. Checklist of United States trees: native and naturalized. U.S. Department of Agriculture, Agriculture Handbook 541. Washington, DC. pp. 375. 

24

25

Liu, Y., \& Nair, M. G. (2011). Labdane diterpenes in Curcuma mangga rhizomes inhibit lipid peroxidation, cyclooxygenase enzymes and human tumour cell proliferation. Food Chemistry, $124,527-532$.

Liu, Y., Singh, D., \& Nair, M. G. (2012). Pods of Khejri (Prosopis cineraria) consumed as a vegetable showed functional food properties. Journal of Functional Food, 4, 116-121.

Mohammed, R. S., Abou Zeid, A. H., El Hawary, S. S., Sleem, A. A., \& Ashour, W. E. (2014). Flavonoid constituents, cytotoxic and antioxidant activities of Gleditsia triacanthos L. leaves. Saudi Journal of Biological Sciences, 21, 547-553.

Nakatani, N., Kayano, S., Kikuzaki, H., Sumino, S., Katagiri, K., \& Mitani, T. (2000). Identification, quantitative determination and antioxidative activities of Chlorogenic acid isomers in Prune (Prunus domestica L.). Journal of Agricultural and Food Chemistry, 48, $5512-5516$.

Panova, D. I., \& Georgieva, E. S. (1972). Flavonoid composition of Gleditschia triacanthos leaves. Doklady Bolgarskoi Akademii Nauk, 25, 71-74.

Park, Y., Moon, B.-H., Lee, E., Lee, Y., Yoon, Y., Ahn, J.-H., \& Lim, Y. (2007). ${ }^{1} \mathrm{H}$ and ${ }^{13}$ C-NMR data of hydroxyflavone derivatives. Magnetic Resonance in Chemistry, 45, 674-679.

Rakhmanberdyeva, R. K., Talipova, M., Gazizov, F., \& Rakhimov, D. A. (2002). Carbohydrates and lipids of Gleditsia triacanthos seeds. Chemistry of Natural Compounds, 38, 24-26.

Ramsewak, R. S., Nair, M. G., Murugesan, S., Mattson, W. J., \& Zasada, J. (2001). Insecticidal fatty acids and triglycerides from Dirca palustris. Journal of Agricultural and Food Chemistry, $49,5852-5856$. 
Roleira, F. M. F., Tavares-da-Silva, E. J., Varela, C. L., Costa, S. C., Silva, T., Garrido, J., \& Borges, F. (2015). Plant derived and dietary phenolic antioxidants: Anticancer properties. Food Chemistry, 183, 235-258.

Sciarini, L. S., Maldonado, F., Ribotta, P. D., Pérez, G. T., \& León, A. E. (2009). Chemical composition and functional properties of Gleditsia triacanthos gum. Food Hydrocolloids, 23, $306-313$.

Seo, C. S., Lim, H. S.; Jeong, S. J., \& Shin, H. K. (2013). HPLC-PDA analysis and anti-inflammatory effects of Mori Cortex Radicis. Natural Product Communications, 8, $1443-1446$.

USDA Plants Database. 1996. Honey locust, Gleditsia triacanthos L.-Plant symbol. U. S. Department of Agriculture, Natural Resources Conservation Service.

Wang, H., Nair, M. G., Strasburg, G. M., Booren, A. M., \& Gray, J. I. (1999). Antioxidant polyphenols from tart cherries (Prunus cerasus). Journal of Agricultural and Food Chemistry, 47, 840-844.

Wang, H., Nair, M. G., Strasburg, G. M., Booren, A. M., Gray, J. I., \& Dewitt, D. L. (2000). Cyclooxygenase active bioflavonoids from Balaton ${ }^{\mathrm{TM}}$ tart cherry and their structure activity relationships. Phytomedicine, 7, 15-19. 
Table $1 .{ }^{1} \mathrm{H}$ and ${ }^{13} \mathrm{C}$ NMR Spectral Data of $1-4$

2

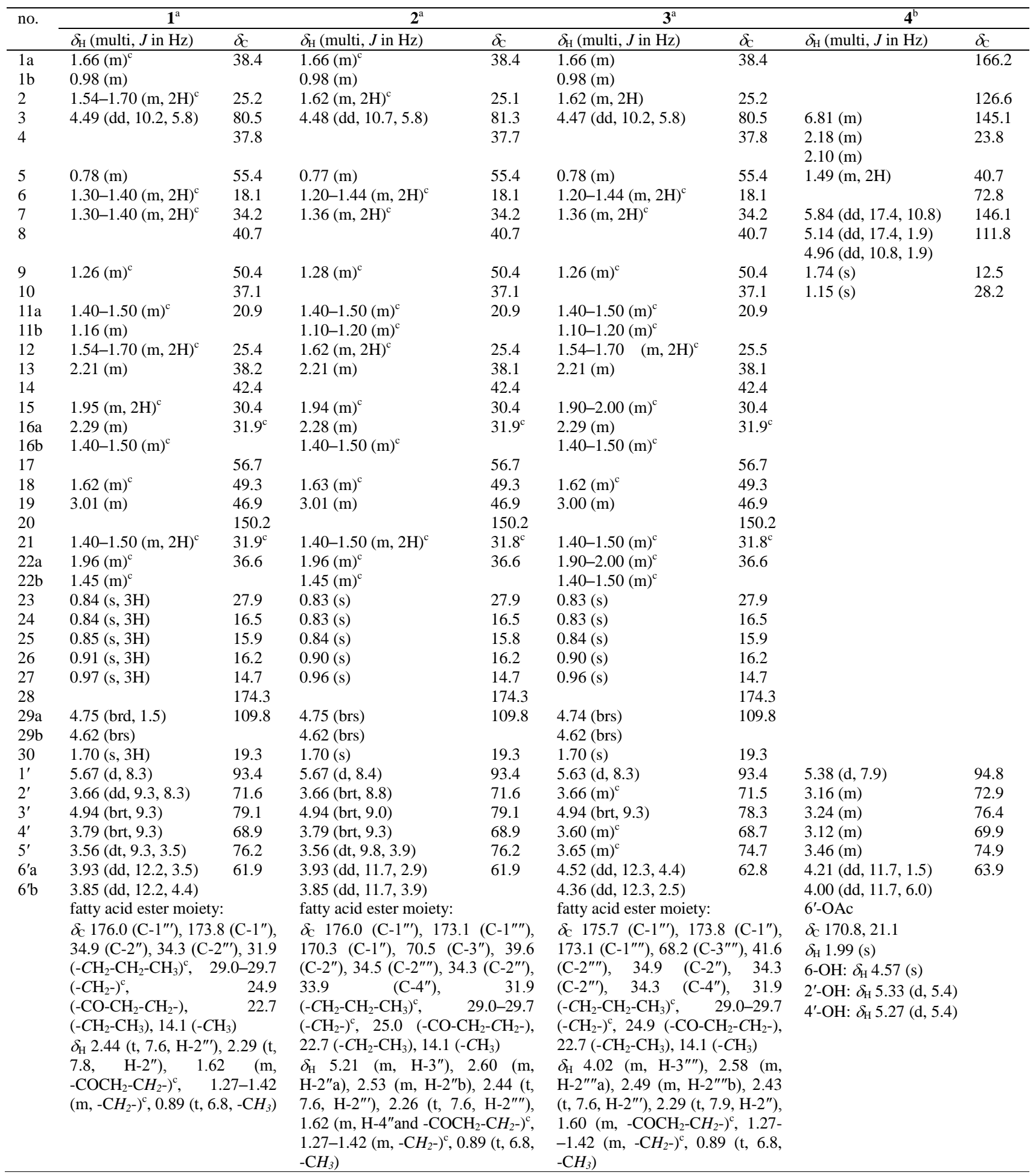

${ }^{\mathrm{a}}$ Data were measured in $\mathrm{CDCl}_{3},{ }^{\mathrm{b}}$ Data were measured in DMSO at $500 \mathrm{MHz}\left({ }^{1} \mathrm{H}\right)$ and $125 \mathrm{MHz}$ $\left({ }^{13} \mathrm{C}\right) .{ }^{\mathrm{c}}$ Signals were overlapped. Italic indicates selected proton and carbon assignments. 


\section{Figure captions}

Fig. 1 - Structures of compounds 1-11 confirmed by NMR and MS spectral experiments.

Fig. 2 - Cyclooxygenase enzymes (COX-1 and -2) inhibitory activity of extracts at $100 \mu \mathrm{g} / \mathrm{mL}$ and pure compounds $1-7$ at $25 \mu \mathrm{g} / \mathrm{mL}$ or $22,18,18,61,72,36$ and $46 \mu \mathrm{M}$, respectively. Positive controls used were NSAIDs aspirin, ibuprofen, Celebrex ${ }^{\circledR}$ and naproxen at 108, 12, 1 and $15 \mu \mathrm{g} / \mathrm{mL}$ or $600,60,2.6$ and $60 \mu \mathrm{M}$, respectively. Vertical bars represent the standard deviation of each data point $(n=2)$. The varying concentrations of positive controls used were to yield a comparable inhibitory activity values between $50-100 \%$ by test extracts, compounds and positive controls alike. 
585

51

52

5436

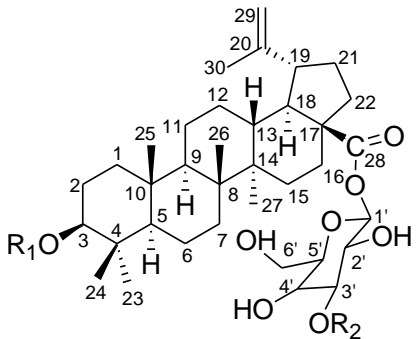

$1 \mathrm{R}_{1}, \mathrm{R}_{2}=-\mathrm{CO}\left(\mathrm{CH}_{2}\right)_{14} \mathrm{CH}_{3},-\mathrm{CO}\left(\mathrm{CH}_{2}\right)_{16} \mathrm{CH}_{3}$

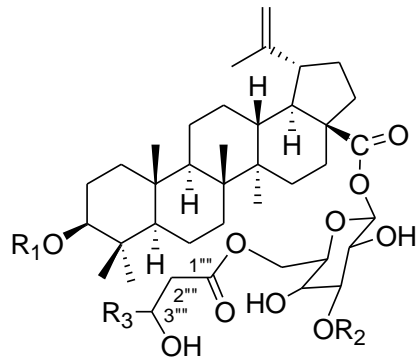

$3 \mathrm{R}_{1}, \mathrm{R}_{2}=-\mathrm{CO}\left(\mathrm{CH}_{2}\right)_{14} \mathrm{CH}_{3},-\mathrm{CO}\left(\mathrm{CH}_{2}\right)_{16} \mathrm{CH}_{3}, \mathrm{R}_{3}=-\left(\mathrm{CH}_{2}\right)_{12} \mathrm{CH}_{3}$
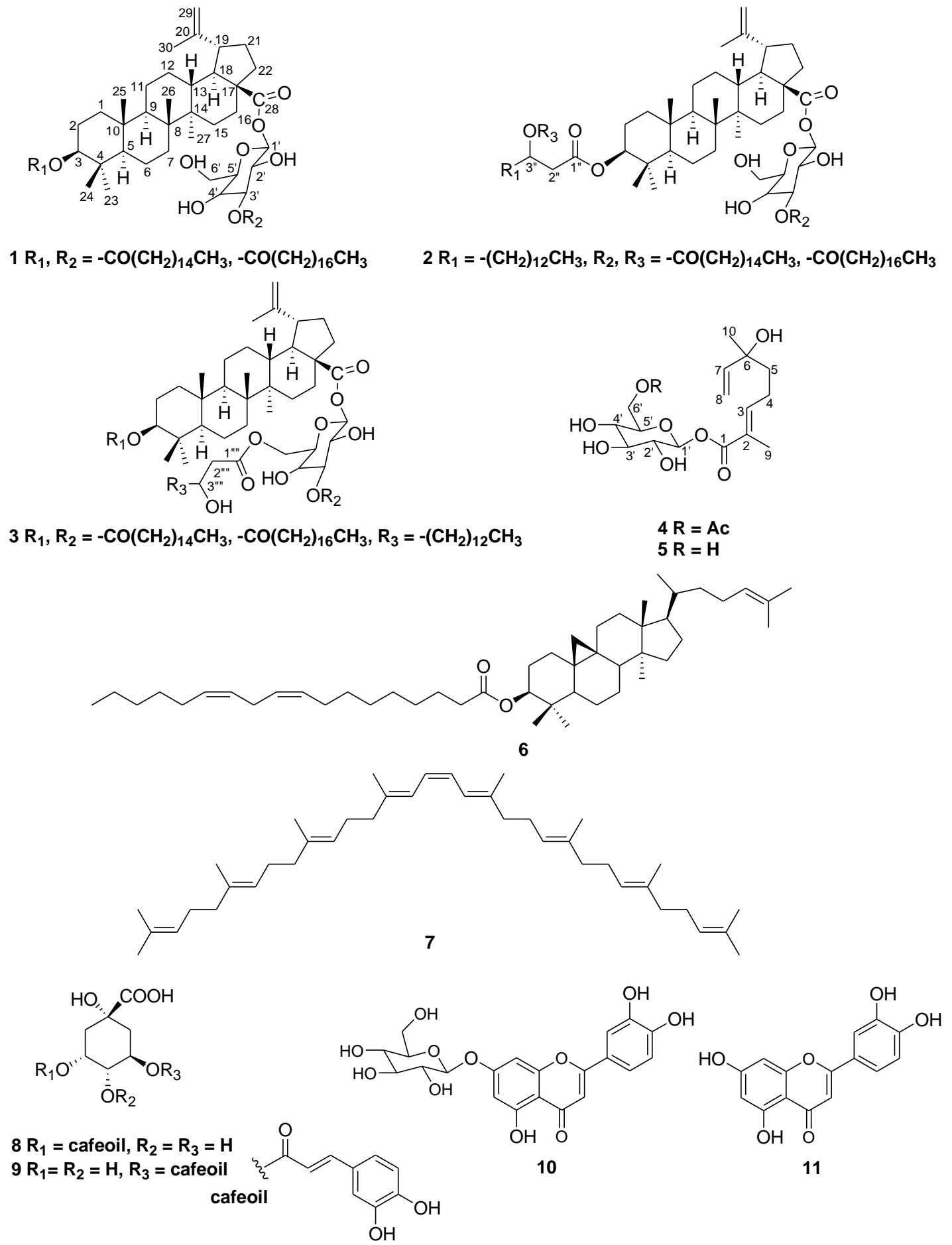

$2 \mathrm{R}_{1}=-\left(\mathrm{CH}_{2}\right)_{12} \mathrm{CH}_{3}, \mathrm{R}_{2}, \mathrm{R}_{3}=-\mathrm{CO}\left(\mathrm{CH}_{2}\right)_{14} \mathrm{CH}_{3},-\mathrm{CO}\left(\mathrm{CH}_{2}\right)_{16} \mathrm{CH}_{3}$

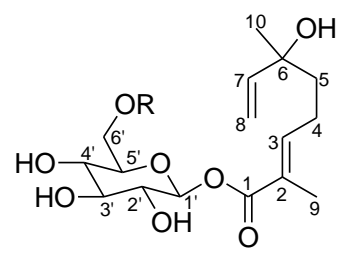

$4 R=A c$

$5 \mathrm{R}=\mathrm{H}$
Fig. 1 


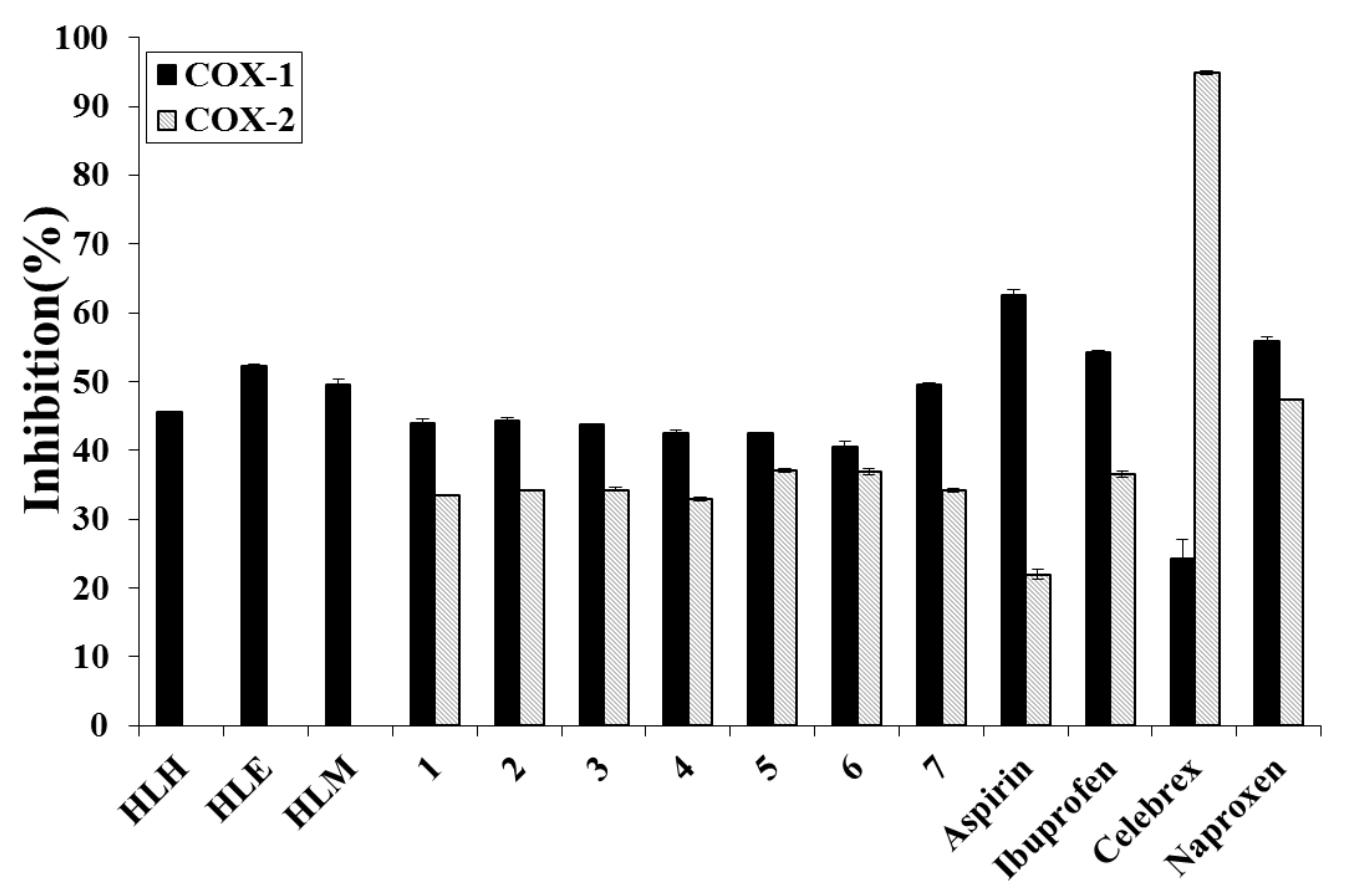

430

291

30

$3 \sqrt{3} 2$
32

Fig. 2

33

34

35

36

37

38

39

40

41

42

43

44

45

46

47

48

49

50

51

52

53

54

55

56

57

58

59

60

61

62 